KS. JAN PIETRZYKOWSKI SDB* - WARSZAWA

\title{
POLSKIE PUBLIKACJE O ŚW. JANIE BOSKO
}

\section{Zagadnienia wstępne}

Od stuleci zakony i zgromadzenia zakonne rozszerzały krąg swego oddziaływania na pobożnych ludzi świeckich za pośrednictwem trzecich zakonów i im pochodnych, bractw, stowarzyszeń religijnych, a od XIX wieku w sposób szczególny poprzez apostolstwo słowa drukowanego. Prasa i książka katolicka początkowo docierała głównie do duchownych i świeckich elit intelektualnych. Uwarunkowane to było głównie dwoma czynnikami: kosztami związanymi z zakupem lub prenumeratą oraz ubóstwem i powszechnym analfabetyzmem prostego ludu (np. matusia Małgorzata, św. Maria Dominika Mazzarello). Ponadto z powodu cenzury państwowej obowiązującej w niektórych krajach i regionach, trudności finansowych, ataków przedstawicieli środowisk liberalnych i masońskich, publicyści i wydawcy proweniencji katolickiej musieli z uporem pokonywać dodatkowe, często nieprzewidziane trudności. $Z$ tych też powodów ukazujące się publikacje o treści religijnej prezentowały niższy poziom wydawniczy niż kół „wywrotowych".

Z powodu braku badań szczegółowych trudno jednoznacznie i precyzyjnie określić w jakim procencie odbiorcami prasy i książki katolickiej w omawianym okresie byli duchowni. Na pewno ich stały kontakt ze słowem drukowanym przyczynił się do wzrostu gorliwości duszpasterskiej i to głównie oni dostarczali wiernym nowych treści chrześcijańskich w świecie ulegającym coraz większemu zeświecczeniu. Wyjściem naprzeciw zapotrzebowaniom religijno-społecznym ludzi tamtego pokolenia okazały się $\mathrm{m}$. in. nowe zgromadzenia i stowarzyszenia zakonne, a wśród nich: asumpcjoniści (Augustiani ab Assumptione) i pallotyni (Societas Apostolatus Catholici). Wiek XIX, to czas powstania wielu nowych zakonów i zgromadzeń. Znacząca ich część, oprócz realizowania własnego charyzmatu, po okresie pewnej konsolidacji struktur, podejmowała misje zagraniczne, prowadziła różnego typu szkoły, poświęcała się duszpasterstwu ogólnemu i specjalistycznemu. Jedną z chętnie podejmowanych aktywności, była działalność wydawnicza. W ten sposób za pomocą różnych form i środków, nowe instytuty życia konsekrowanego włączały się w posłannictwo Kościoła powszechnego. W ten nurt aktywnie wpisał

* Ks. Jan Pietrzykowski SDB - dr hab. historii, prof. UKSW, dyrektor Archiwum Inspektorii św. Stanisława Kostki w Warszawie, wykładowca w WSD Towarzystwa Salezjańskiego w Lądzie nad Wartą. 
się św. Jan Bosko przez działalność pisarską i wydawniczą, zarówno sam jak i poprzez założone Towarzystwo św. Franciszka Salezego.

Okres działalności wychowawczej i duszpasterskiej Apostoła turyńskiej młodzieży męskiej charakteryzował się znacznym wpływem prasy katolickiej na rozwój życia religijnego. Informowała ona wiernych o bieżących wydarzeniach politycznych i społecznych, a także podawała wiadomości, komunikaty i artykuły o tematyce moralnej i ascetycznej. Ta współczesna katolicka forma rozwoju środków masowego przekazu informacji najpierw rozwinęła się w krajach niemieckojęzycznych: Der Katholik w Moguncji (1821 r.), Kolnische Volnische Volkszeitung (1869 r.), a w Austrii Vaterland (1860 r.). Od 1861 r. Stolica Apostolska w Rzymie rozpoczęła edycję Osservatore Romano, przeznaczone dla duszpasterzy, osób konsekrowanych i wiernych świeckich ${ }^{1}$.

W połowie XIX wieku na ziemiach polskich czasopisma katolickie zaczęto wydawać we wszystkich trzech zaborach. W Krakowie od 1848 r. ukazywał się Czas, na Śląsku i Pomorzu wydawano Katolik (1868-1869 r.), w Warszawie wychodził Przeglad Katolicki (1863 r.) i wiele innych².

\section{Periodyki salezjańskie $w$ języku polskim}

Założyciel Towarzystwa św. Franciszka Salezego, św. Jan Bosko, dla powstałego w roku 1876 Związku Pomocników Salezjańskich rozpoczął wydawać periodyk - Bibliofilo Cattolico (1877 r.), a po dwóch latach zmienił tytuł na Bollettino Salesiano". W tym czasopiśmie salezjanie przekazywali propozycje pomocnikom świeckim i duchownym oraz udzielali informacji o swojej działalności. Bolletino Salesiano od początku pełniło rolę takiego quasi łącznika pomiędzy Zgromadzeniem a Pomocnikami Salezjańskimi ${ }^{3}$.

Periodyk ten w wersji francuskiej Bulletin Salesion (wyd. od 1879) docierał na ziemie polskie, głównie do odbiorców w zaborze austriackim, już za życia św. Jana Bosko. Z tej części Polski przemytem trafiał on do czytelników znajdujących się pod okupacją rosyjską. Natomiast w zaborze pruskim nieco później rozprowadzano niemiecką wersję Salesianer Don Boscos wychodzącą od roku 1895 w monarchii austro-węgierskiej. Lektura tych czasopism znacznie przygotowywała grunt pod przyszłe zakłady salezjańskie na ziemiach polskich ${ }^{4}$.

Zapotrzebowanie Polaków było duże na łatwą i interesującą lekturę katolicką. Wychodząc naprzeciw oczekiwaniom społecznym od stycznia $1898 \mathrm{r}$. w Turynie w nakładzie ponad 50.000 egzemplarzy pod redakcją ks. Wiktora Grabelskiego (1857-1902) rozpoczęto wydawać Wiadomości Salezjańskie - polską wersję biu-

\footnotetext{
${ }^{1}$ Por. B. Kumor, Historia Kościoła, t. 7, Lublin 1991, s. 301-302; K. Burski, ,, Osservatore Romano L",', Encyklopedia katolicka, t. 14, red. E. Gigilewicz, Lublin 2010, kol. 920-921.

${ }^{2}$ Por. K. Szczęch, Rocznik Statystyczny Kościoła katolickiego w Polsce. Rok 1937, Lublin 1938.

${ }^{3}$ Por. J. Pietrzykowski. Salezjanie w Polsce 1945-1989, Warszawa 2007, s. 350.

${ }^{4}$ E. Ceria, Annali della Societá Salesiana, vol. 2, Torino 1945, p. 670; A. Świda, Piśmiennictwo wychowawcze św. Jana Bosko, „Nostra. Biuletyn Salezjański”, 1979 nr 179, s. 20; http:// de.wikipedia.org/wiki/Salesianer_Don_Boscos z 27 VII 2012 r.
} 
letynu włoskiego Bolletino Salesiano. Od 1902 r. do początku roku 1915 Wiadomości redagowano w Oświęcimiu, ale nadal drukowano w Turynie. Czasopismo zawieszono z powodu trudności wojennych. W grudniu 1916 r. wznowiono wydawanie periodyku, ale już pod zmienionym tytułem - Pokłosie Salezjańskie, drukowane w Raciborzu, Krakowie, Mikołowie, a od 1923 r. w Warszawie. Było ono bardziej samodzielne, wychodzące jako miesięcznik (kwartalnik) Inspektorii św. StanisławaKostkizsiedzibą w Oświęcimiu, a od 1922 r. w Warszawie. Razemz przeniesieniem siedziby Inspektoratu do stolicy II Rzeczpospolitej, także redakcja Pokłosia Salezjańskiego znalazła się w Warszawie. W tamtejszym Zakładzie im. Ks. Jana Siemca salezjanie prowadzili drukarnię przy Rzemieślniczej Szkole Graficznej. Periodyk ukazywał się dość regularnie do wybuchu II wojny światowej i następnie w latach 1946-19495.

Układ treści Pokłosia Salezjańskiego odpowiadał założeniom określonym w temacie niniejszego opracowania. Do stałych działów tego periodyku należały m.in.: krótki rys życia i dzieł św. Jana Bosko, myśli i zdania Apostoła Młodzieży, kronika zakładów szkolno-wychowawczych i duszpasterskich, artykuły o tematyce religijno-moralnej, łaski Maryi Wspomożycielki, wiadomości misyjne. Ponadto w latach 1932-1937 wychodził bezpłatny dodatek - Posłaniec św. Jana Bosko w objętości od 4 do 8 stron $^{6}$.

Po zlikwidowaniu Pokłosia Salezjańskiego przez władze komunistyczne, rolę biuletynu polskiego pełniła Nostra, wydawana początkowo na powielaczu w Krakowie. Do 1959 r. miała ona charakter periodyku wewnętrznego, w rodzaju listu inspektora kierowanego do współbraci. W latach następnych czasopismo zostało podzielone na poszczególne działy. Dopiero od roku 1969 Nostra stała się periodykiem dwóch, a następnie (1980 r.) czterech inspektorii polskich. Tematyka związana z życiem i działalnością św. Jan Bosko była ciągle obecna na łamach tego miesięcznika. Ukazywały się też numery okolicznościowe monotematyczne, poświęcone sylwetkom zasłużonych salezjanów, św. Janowi Bosko, misjom salezjańskim itd. Od stycznia 1986 r. pismo (Biuletyn Salezjański. Nostra) wychodziło na lepszym papierze, zmienionej szacie graficznej i w nakładzie 2.000 egzemplarzy ${ }^{7}$.

We wrześniu 2000 r. „Biuletyn Salezjański” zamieniono na kolorowy Don Bosco - magazyn salezjański. Redakcję czasopisma przeniesiono z Krakowa do Poznania na terenie inspektorii wrocławskiej. Dokonano gruntownego przeobra-

${ }^{5}$ Por. M. Wziętek, Pokłosie Salezjańskie. Monografia czasopisma, Lublin 1988, s. 2-5, mps; A. Świda. Droga do samodzielności polskiej prowincji salezjańskiej, Warszawa 1990, s. 56-58; W. Żurek. Szkoty salezjańskie w Oświęcimiu na tle szkolnictwa średniego ogólnokształcacego i zawodowego na ziemiach polskich 1900-1939, Lublin 2010, s. 12-13.

${ }^{6}$ Encyklopedia wiedzy o prasie, Wrocław 1976, s. 71; Bibliografia katolickich czasopism religijnych w Polsce 1918-1944, red. Z. Zieliński, Lublin 1981, s. 86, 220.

${ }^{7}$ ASIW. T. Protokoły Rad Inspektorialnych 1969-1971, Częstochowa 16 X 1969; T. Konsulta, Sprawozdanie ze spotkania Konsulty Konferencji Salezjańskich Inspektorii Polskich w Częstochowie w dniu 28 V 1986, s. 6 (mps); „Biuletyn Salezjański. Nostra” 1989 nr 304; D. Zamiatała, Zakony męskie w polityce władz komunistycznych w Polsce w latach 1945-1989, t. 2. Działalność duszpasterska i spoleczna zakonów w latach 1945-1989, Warszawa 2012, s. 329. 
żenia periodyku pod względem zespołu redakcyjnego, szaty graficznej, nakładu itp. Zagadnienia związane z osobą i działalnością ks. Bosko są nadal obecne na łamach tego miesięcznika. Poza okazjonalnymi informacjami ukazują się też numery problemowe dotyczące jednego aspektu, np. z dziedziny duchowości czy wychowania ${ }^{8}$.

Kolejnym czasopismem, które wychodziło w środowisku salezjańskim i zawierało informacje o św. Janie Bosko, był miesięcznik Bazylika, wydawany przy parafii Najświętszego Serca Jezusowego w Warszawie na Pradze. Pismo to - jako nowatorski środek oddziaływania duszpasterskiego było dziełem ostatniego diecezjalnego proboszcza bazyliki, ks. Jana Poskróbko, który erygował je we wrześniu 1926 r. Kiedy w 1931 r. arcybiskup warszawski kard. Aleksander Kakowski przekazał parafię i bazylikę salezjanom, ci kontynuowali edycję tego periodyku do lipca 1939 r. nakładzie od 1.000 (1931 r.) do 2.000 (1938 r.) egzemplarzy 9 Treści przekazywane przez to czasopismo nie były ujęte w określone działy, ale jednak tworzyły pewien schemat. Stałe miejsce w tym schemacie zajmowały artykuły o problematyce hagiograficznej, szczególnie dotyczące założyciela Towarzystwa Salezjańskiego ${ }^{10}$.

Podobnie było w przypadku innych lokalnych miesięczników salezjańskich. Nieodłączną ich częścią były informacje dotyczące ks. Bosko. Należały do nich m. in.: wychodzący w nakładzie 1.200 egzemplarzy Posłaniec z Jasnej Góry Czerwińskiej redagowany (1926-1930) w domu nowicjackim w Czerwińsku nad Wisłą, czy Dzwonek św. Teresy - w nakładzie 1.000 egzemplarzy, wydawany i redagowany" (1933-1937) przez proboszcza parafii pw. Św. Teresy od Dzieciątka Jezus w Łodzi ${ }^{11}$.

W okresie międzywojennym od 1923 r. działalność wydawnicza salezjanów polskich koncentrowała się głównie przy Szkole Rzemiosł w Warszawie. Warsztaty szkolne mogły właściwie prosperować dzięki realizacji zamówień przychodzących z inspektoratów z Warszawy i Krakowa. W Zakładzie im. Ks. Jana Siemca $\mathrm{w}$ Warszawie funkcjonowało jeszcze wydawnictwo periodyczne o nakładzie 5.000 egzemplarzy małego formatu - Kłosy z Bożej Roli. Była to seria 58 krótkich biografii świętych, błogosławionych i sług Bożych ${ }^{12}$.

Z inicjatywy salezjańskich pracowników dydaktyczno-naukowych Katolickiego Uniwersytetu w Lublinie w 1975 r. ukazał się pierwszy rocznik Seminare. Poszukiwania naukowo-pastoralne jako organ Wyższych Seminariów Duchow-

\footnotetext{
${ }^{8}$ Por. A. Paszek, Wychowanie w duchu ks. Bosko, „Don Bosco”, maj/czerwiec 2001, s. 16-17.

${ }^{9}$ ASIW. Ks. Dr Antoni Hlond salezjanin - kompozytor, zebrał ks. P. Golla SDB, t. 18, Ląd 1973 s. 138-209, mps.

${ }^{10}$ Por. S. Chrobak, Bazylika (1926-1939) monografia czasopisma, Lublin 1988, s. 26-27, mps.

${ }^{11}$ Por. W. Mysłek, Kościót katolicki w Polsce w latach 1918-1939 (Zarys historyczny), Warszawa 1966, s. 238; Bibliografa katolickich czasopism religijnych w Polsce, s. 230; S. Styrna, Zgromadzenie Salezjańskie w Polsce w poszukiwaniu form odpowiedzi na potrzeby wychowawcze i duszpasterskie w latach 1898-1974, w: 75 lat działalności salezjanów w Polsce. Księga pamiątkowa, red. R. Popowski, S. Wilk, M. Lewko, Łódź-Kraków 1974, s. 17.

${ }^{12}$ W. Nowaczyk, Rozdziat podwójnie zamknięty, t. 1. Szkice z dziejów Fundacji i Zakładu im. Ks. Jana Siemca w Warszawie 1919-1944, Puszczykowo 1982, s. 159-160, mps.
} 
nych Towarzystwa Salezjańskiego w Lądzie i w Krakowie. Tom z roku 19871988 został w całości poświęcony św. Janowi Bosko w ramach obchodów setnej rocznicy śmierci założyciela Towarzystwa Salezjańskiego ${ }^{13}$.

Problematykę związaną z ks. Bosko i jego dziełem poruszano okazjonalnie w salezjańskim miesięczniku Ziarna. Było to czasopismo kolorowe w formacie A4, ukazujące się w nakładzie od 2.000 do 7.000 egzemplarzy i skierowane do młodzieży. Wychodziło w latach 1989-2001. Wydawała je Inspektoria św. Stanisława Kostki z siedzibą w Warszawie ${ }^{14}$.

\section{Pozycje książkowe do wybuchu II wojny światowej}

Pierwsze próby opracowania polskich druków zwartych o księdzu Janie Bosko i jego działalności szkolno-wychowawczej i duszpasterskiej podjęto dość późno. Wprost pionierski krótki spis książek i broszur jakie wydano do $1939 \mathrm{r}$. opracował ks. Andrzej Świda, kierownik Archiwum Salezjańskiego Inspektorii Warszawskiej. Jego zestaw: Polskie druki o ks. Bosko i jego dziele. Łódź-LądKraków 1972, choć bardzo cenny i dokładny pozostaje nadal w maszynopisie. Lukę tę $\mathrm{w}$ jakimś stopniu wypełnia zamieszczona w księdze pamiątkowej bibliografia salezjanów polskich za lata 1897-1974, zebrana starannie przez ks. Stanisława Wilka. Jest to z pewnością wartościowe opracowanie, ponieważ oprócz publikacji zawiera ono także thumaczenia książek obcojęzycznych na język polski. Wykaz ten został ułożony alfabetycznie według haseł autorskich ${ }^{15}$. Z kolei ks. Kazimierz Szczerba w artykule „Kontakty Polaków z księdzem Janem Bosko"16 omówił w jednym z paragrafów pierwsze żywoty Apostoła Młodzieży, które zostały przetłumaczone i wydane w języku polskim. Większość z nich jest przechowywana i dostępna w bibliotekach seminaryjnych i znajdujących się przy centralnych archiwach inspektorialnych.

Za życia ks. Bosko, z upoważnienia autora francuskiego, lekarza Karola d'Espinay w 1886 r. we Lwowie ukazał się drukiem przekład nieznanego tłumacza Ksiadz Bosco, ss. 169. Bez imprimatur pozycja została wydana w Drukarni

${ }^{13}$ Archiwum Akt Nowych w Warszawie, Wydział do Spraw Wyznań (dalej AAN Wd/sW), sygn. 133/129, Ks. S. Styrna do Głównego Urzędu Kontroli Prasy, Publikacji i Widowisk w Warszawie, Łódź 29 X 1976; A. Dziędziel, F. Żołnowski, Stowo wstęne, „Seminare. Poszukiwania naukowopastoralne", 1975, s. 5.

${ }^{14}$ Od października 1980 r. kl. Grzegorz Jaskot przy współpracy kolegów z Wyższego Seminarium Duchownego w Lądzie rozpoczął redagować „List formacyjny” dla kandydatów do Towarzystwa Salezjańskiego. Wkrótce „List” przemianowano na „Ziarna”, które przez dziewięć lat wychodziły w formie powielaczowej poza zasięgiem cenzury państwowej. W 1999 r. ksiądz inspektor Józef Struś wymienił redaktora naczelnego, a w roku 2001 zawiesił wydawanie tego miesięcznika. Por. ASIW. T. Ziarna, Sprawozdania; Salezjańskie pismo o problematyce dorastającej młodzieży, „Słowo Powszechne”, 1990, nr 59, s. 9.

${ }^{15}$ Por. S. Wilk, Materiaty do bibliografii publikacji salezjanów polskich za lata 1897-1974, w: 75 lat działalności salezjanów w Polsce, s.278-345.

${ }^{16}$ K. Szczerba, Kontakty Polaków z księdzem Janem Bosko, „Seminare. Poszukiwania naukowo-pastoralne”, Kraków-Ląd 1998-1988, s. 111-137. 
Ludowej. Biografia ta zareklamowała wybitnego pedagoga polskiemu społeczeństwu. W tym samym roku nakładem Przeglądu Katolickiego, z imprimatur Kurii Warszawskiej i za pozwoleniem cenzury rosyjskiej na 160 stronach ukazało się nieznanego autora trzecie wydanie pozycji: Ksiadz Jan Bosko, opiekun i nauczyciel sierot ${ }^{17}$.

W 1887 r. nakładem Księgarni Katolickiej w Poznaniu ukazała się trzecia biografia założyciela salezjanów autorstwa Ludwika Noëla Ksiądz Bosko, jego żywot i czyny podtug różnych źródet opracowane. Jest niewielką, popularną książką o objętości 90 stron $^{18}$.

Osobą i dziełem turyńskiego wychowawcy młodzieży męskiej dość wcześnie zainteresowało się środowisko krakowskie. W 1886 r. oddział drukarni Gebethner i Ska opublikował ułożoną przez ks. Bosko Nowennę do Najświętszej Maryi Panny Wspomożycielki chrześcijan. W $1886 \mathrm{r}$. ta sama oficyna wydawnicza zainteresowała czytelnika publikacją Michała Krzemienia Dla dzieci, Józio Mularczyk $i$ ksiadz Jan Bosko. Było to jedno z pierwszych opowiadań o ks. Janie Bosko, które zaczęły się pojawiać równolegle do biografii Świętego.

W pierwszym roku (1889) po śmierci Apostoła Młodzieży do rąk polskiego odbiorcy trafił następny życiorys o objętości 75 stron Ksiądz Jan Bosko, wydany nakładem Władysława Miłkowskiego, autorstwa hrabiny Otyldy Stadnickiej, posługującej się pseudonimem M. O. S. Jednocześnie ukazał się w Krakowie (nakładem salezjanów) przekład książki włoskiego salezjanina ks. Jana Lemoyne, $O M a$ tusi Małgorzacie. Obrazki z życia świątobliwej Matgorzaty Bosco, matki ks. Jana Bosco, założyciela i generała Zgromadzenia ks. Salezjanów, nakładem salezjanów. Lektura tej pozycji dostarcza jednak więcej treści i informacji związanych lub dotyczących osoby ks. Bosko i jego Oratorium. Tłumaczenie zostało przygotowane przez pierwszych polskich salezjanów w Turynie, a sfinalizowane prawdopodobnie przez rodzinę Czartoryskich. Dopiero po sprowadzeniu polskich czcionek drukarskich do Turynu, zaczęto od 1896 r. wydawać publikacje Pomocnicy salezjańscy czyli sposób praktyczny podniesienia obyczajów w społeczeństwie ${ }^{19}$.

Tłumaczenie i wydawanie ambitniejszych i obszerniejszych opracowań dotyczących życia i działalności ks. Bosko okazało się łatwiejsze dopiero po powstaniu pierwszych domów salezjańskich na ziemiach polskich. Nakładem Zakładu Salezjańskiego w Oświęcimiu w 1905 r. wydrukowano w Krakowie na 184 stronach w słabym tłumaczeniu System wychowawczy przyjęty w domach Zgromadzenia Salezjańskiego założonego przez ks. Jana Bosko. Staraniem i nakładem tego domu macierzystego w 1913 r. w Drukarni „Katolika” w Bytomiu wydano popularny Żywot Wiel. Stugi Bożego Ks. Jana Bosko (Vita breve e popolare di d. Giovanni Bosco), autorstwa salezjanina włoskiego, ks. Jana Francesia, ss. 407. Z ję-

${ }^{17}$ W 1878 r. na łamach „Bollettino Salesiano” opublikowano anonimowo Storia dell' oratorio di San Francesco di Sales, pióra Jana Bonettiego. Z tego źródła prawdopodobnie korzystał polski thumacz i opublikował w roku 1883 pierwsze wydanie, a po roku drugie w redakcji Przeglądu Katolickiego w Warszawie. Por. Szczerba, Kontakty Polaków z księdzem Janem Bosko, s. 114.

${ }^{18}$ Por. A. Świda, Polskie druki o ks. Bosko i jego dziele, Łódź-Ląd-Kraków 1972, s. 2-3.

${ }^{19}$ Szczerba, Kontakty Polaków z księdzem Janem Bosko, s. 114-115. 
zyka francuskiego tekst przetłumaczył ks. Antoni Kotarski (1873-1953) ${ }^{20}$. Podobnie też ks. Aleksy Siara, pracujący w domu formacyjnym Krakowie z języka niemieckiego przygotował do druku popularny żywot autorstwa Franciszka Kerera - Ksiadz Bosko, ss. 100, wydany w Oświęcimiu w 1921 r. ${ }^{21}$

W okresie międzywojennym, polscy salezjanie w kraju największą aktywnością wydawniczą wykazali się w latach określonych datami beatyfikacji i kanonizacji Ojca i nauczyciela Młodzieży. Pierwszy, obszerniejszy i samodzielny życiorys opracował ks. Jan Romanowicz (1891-1961) - Błogosławiony Ks. Jan Bosko, Warszawa 1929, 1932, ss. 171. Publikacja została przygotowana głównie na podstawie Memorie Biografiche. Przystępną narracją autor zamierzał dotrzeć do najszerszych warstw społecznych i zapoznać ich postacią nowego błogosławionego. Pozycja ta pośrednio miała wpływ na wydawanie anonimowych broszur: Błogosławiony Pastuszek, Kraków 1929, ss. 32; pod zmodyfikowanymi tytułami - Błogostawiony Jan Bosko, wyd. 2, Kraków 1931, Dobroczyńca ludzkości. Cuda i łaski bł. Jana Bosko, Kraków 1931. Nakładem Księgarni św. Wojciecha w Poznaniu w 1933 r. Ludwika Jelesińska z ilustracjami Marii Jaroszyńskiej wydała O Janku który umiał chcieć. Dziecięctwo błogosławionego Jana Bosko, ss. 75. Jest pięknie opracowany i przeznaczony dla młodych czytelników zbiór faktów z życia założyciela salezjanów.

Postać i dzieła św. Jana Bosko była obecna i popularna w różnych wydawnictwach ciągłych. We wspomnianej już serii wydawniczej Wydawnictwa Salezjańskiego w Warszawie Kłosy z Bożej Roli, jako pierwszy, żywot pt. Święty Jan Bosko, (Warszawa 1934, wyd. 2. Warszawa 1946, ss. 32) w formie ilustrowanej zamieścił ks. Marian Kubrycht (1901-1967). Ks. Antoni Śródka (1890-1981) przygotował życiorys w formie albumu pt. Św. Jan Bosko. Wydarzenia z życia wielkiego Apostoła Młodzieży, Poznań 1935, ss. 64. Anonimowo wydał on, Święty Jan Bosko. Dzieło św. Jana Bosko, Przemyśl 1938, ss. 32. W 1935 r. w serii „Postacie Świętych" w tomie 59, nakładem i drukiem Księgarni św. Wojciecha w Poznaniu J. Kisielewski opracował mały żywot $S_{\text {w }}$. Jan Bosko $1815-1888$ przeznaczony dla inteligencji. Biblioteczka Radość życia Nr 19 emitowała książkę Marii Kączkowskiej, Bt. Jan Bosko, Warszawa 1930, ss. 126. Autorka zamieściła interesujące anegdoty z życia bohatera i 12 ilustracji z pocztówek salezjańskich ${ }^{22}$.

Postać Apostoła Młodzieży była także tematem różnych utworów warsztatowych, przygotowywanych do deklamacji lub pieśni. Odbiorcą sztuk scenicznych były przede wszystkim domy salezjańskie wychowujące młodzież męską. Przeznaczone one były dla młodzieży i ludu. W latach 1934-1935 po kanonizacji ks. Bosko Biblioteczka Teatralna podjęła druk niektórych sztuk scenicznych przygotowanych przez Zofię Topińską jak: Wśród cierni i róż. Obrazki historyczne z życia św. Jana Bosko w 3-aktach i żywych obrazach, Warszawa 1934, ss. 98. Kolejne sztuki tej autorki wydano w roku następnym: Na łące w Becchi. Obrazek sceniczny z życia Jana Bosko, ss. 20; Pierwszy własny dom, ss. 21; Przy warsztatach.

${ }^{20}$ ASIW. T. Personalna ks. A. Kotarskiego, thumaczenia.

${ }^{21}$ Autor korzystał z dwutomowego dzieła ks. G. B. Lemoyne, Vita del venerabile servo di Dio Giovanni Bosco, vol. 1-2, Torino 1922.

${ }^{22}$ Świda, Polskie druki o ks. Bosko i jego dziele, s. 14-22. 
Obrazek sceniczny, 1935 ss. 13; U krawca $w$ Chcieri. Obrazek sceniczny z życia Jana Bosko, ss. 15; Więźniowie w Turynie. Obrazek; Zaraza w Turynie, ss. 9. Ponadto salezjanie wydali też sztukę Anny Zahorowskiej, $W$ cieniu Oratorium, Warszawa 1934. Po 1935 r. Wydawnictwo Salezjańskie zrezygnowało z kontynuacji druku Biblioteczki Teatralnej. Tylko w 1938 r. wydano broszurę informującą pt. Dzieto św. Jana Bosko przeznaczone dla dobrodziejów i sympatyków salezjanów. Wacław Romanowski na podstawie życiorysu ks. Bosko autorstwa A. Auffraya przygotował Obrazki z życia św. Jana Bosko w dwóch czesściach. Praca została wydrukowana w 1939 r. w Miejscu Piastowym ${ }^{23}$.

Wśród polskich publikacji zwartych wydanych o założycielu salezjanów można jeszcze wyróżnić prace dotyczące jego życia wewnętrznego i pedagogii systemu prewencyjnego. Ks. Zygmunt Kuzak (1901-1988) opublikował w Wydawnictwie Salezjańskim Życie wewnętrzne św. Jana Bosko wedtug Ceria: Don Bosco con Dio, Warszawa 1938, ss. 137. Jest to wolny przekład autoryzowany przez autora. Ponadto ks. Kuzak na podstawie lektury włoskiej opublikował popularną książkę pt. Wspomożycielka św. Jana Bosko, Warszawa 1937, ss. 81. Ks. Józef Heintzel (1873-1942), korzystając z hiszpańskojęzycznej pozycji Rudolfa M. Firro Torresa, przygotował dla polskiego czytelnika własną pracę, Przez niwę pedagogiczna. Konferencje o systemie prewencyjnym Jana Bosko, Warszawa 1929, ss. 246. Na rynku polskim znalazła się książka Augustyna Auffraya, Pedagogia świętego (Il metodo educativo del ven. G. Bosco), Warszawa 1932 ss. 120. Przekład autoryzowany z języka włoskiego wykonała Anna Zahorska. Jest to dobra pozycja popularyzująca system prewencyjny Wychowawcy młodzieży. Międzywojenne wydawnictwa poświęcone Janowi Bosko zamykają dwa tłumaczenia z języka włoskiego: Mistrz wychowania współczesnego i ks. Antoniego Kotarskiego, System wychowawczy św. Jana Bosko wedlug B. Fascie, (Metodo educativo di don Bosco), ss. 132. Autor, były wychowanek salezjański, w sposób popularny zaprezentował pedagogię salezjańską ${ }^{24}$.

\section{Sytuacja wydawnicza w powojennej rzeczywistości}

Po zakończeniu II wojny światowej, w zmienionych warunkach politycznych i ustrojowych salezjanom - mimo piętrzących się trudności - udało się reaktywować w Warszawie swoje Wydawnictwo i Drukarnię, które funkcjonowały tylko do 1949 r. Jedną z pierwszych wydanych po wojnie pozycji była publikacja z 1946 r. zawierająca teksty trzech nowenn: do Matki Bożej Wspomożenia Wiernych, Najświętszego Serca Pana Jezusa i św. Jana Bosko w nakładzie 10.000 egzemplarzy. Z drukarni przy ul. Wiślanej (dawniej ks. J. Siemca) w 1948 r. wznowiono pozycję: O Janku przyjacielu młodzieży, pióra Marii Kaczkowskiej, która prawa autorskie przekazała salezjanom ${ }^{25}$.

${ }^{23}$ Por. M. Lewko. Czemu stużyt teatr zaktadowy?, w: 75 lat działalności salezjanów w Polsce. s. $132-134$.

${ }^{24}$ Por. Wilk, Materiaty do bibliografii, s. 295, 309.

${ }^{25}$ ASIW. T. Protokoły z Rad Inspektorialnych. Łódź 28-30 IV 1946; T. Wydawnictwo - Książki drukowane. 
Likwidacja zdecydowanej większości drukarni i wydawnictw katolickich przez władze komunistyczne, ograniczanie przydziału papieru wegetującym jeszcze wydawnictwom oraz wroga działalność cenzury państwowej zahamowały na kilkadziesiąt lat aktywność publicystyczną salezjanów polskich. Do wznowienia działalności Wydawnictwa Salezjańskiego w 1976 r. na rynku polskim nie wiele ukazało się na temat życia i posługi św. Jana Bosko W tym trudnym okresie salezjanie sporadycznie korzystali z innych wydawnictw. Ks. Ignacy Kuczkowicz SDB przetłumaczył na język polski poszukiwaną pozycję ks. Piotra Braido, System wychowawczy księdza Bosko, którą w Warszawie w roku 1971 wydano na powielaczu. Do wyjątków wydawniczych należy broszura, Don Bosco, Rzym 1972, ss. 32, przygotowana przez ks. Z. Kuzaka na Kongres Powołań. Formalności związane z drukiem i sprowadzeniem do kraju trwały ponad dwa lata ${ }^{26}$.

Kończący się okres rządów komunistycznych w Polsce umożliwiał już wydawanie więcej pozycji książkowych w ciągu roku i to w dużych nakładach. Po nawiązaniu oficjalnych kontaktów z Wydawnictwem Elle Di Ci w Turynie do rąk polskiego czytelnika masowo trafiały książki znane w całym Towarzystwie Salezjańskim. W roku 1987 opublikowano w nakł. 5.000 egz. źródłową pozycję dla salezjanów napisaną przez św. Jana Bosko, Wspomnienia Oratorium (Memorie), którą kilkakrotnie wznawiano w następnych latach. W połowie lat osiemdziesiątych ubiegłego wieku dużą popularnością cieszyły się Sny, wizje św. Jana Bosko, Łódź 1984 nakł. 20.000 egz.; Warszawa 1989 nakł. 40.000. Wyjątkowym wprost powodzeniem cieszył się Teresio Bosco i jego autorstwa Spetniony sen. Opowieść biograficzna o św. Janie Bosko, który w krótkim czasie miał 8 wydań o łącznym nakładzie 200.000 egzemplarzy. Luciano Cian swoimi pozycjami: System zapobiegawczy św. Jana Bosko (Il Sistema Preventivo di Don Bosco e i lineamenti caratteristici del suo stile), Warszawa 1986 i Wychowanie w duchu księdza Bosko (Educhiamo i giovani d'oggi come Don Bosco), Warszawa 1989, 1991, 2001 zyskał sobie sympatię czytelnika polskiego. W roku 1989 r. wydano w dwóch nakładach, 20.000 i 50.000 egzemplarzy publikację M. Marie Vadndewalle, Św. Jan Bosko przyjaciel dzieci ${ }^{27}$.

Kolejną - tym razem typowo polską - pozycją poświęconą Janowi Bosko, była książka ks. Władysława Kołyszko, wikariusz inspektora w Pile. W związku z obchodami setnej rocznicy śmierci założyciela Zgromadzenia, zebrał on od salezjanów polskich i przygotował do druku 75 kazań o św. Janie Bosko pt. Ojciec $i$ nauczyciel (nakł. 2.500 egz.). Publikacja została podzielona na cztery bloki tematyczne: człowiek, wychowawca, założyciel, święty ${ }^{28}$.

Kl. Jacek Jurczyński SDB podczas praktyki pedagogiczno-duszpasterskiej w Wiedniu zapoznał się z publikacją Waltera Nigga, którą później przetłumaczył z języka niemieckiego na polski, Święty naszych czasów, Warszawa 1989, ss. 123. Treść książki odbiega od wcześniejszych biogramów i przedstawia żywy obraz człowieka, który wykraczał poza przyjęte w XIX wieku przyjęte ramy święto-

${ }^{26}$ ASIW. T. Protokoły Rad Inspektorialnych 1971-1973., Łódź 28 I 1972.

${ }^{27}$ ASIW. T. Wydawnictwo, K. Jakubowski. Z dziejów Wydawnictwa Salezjańskiego w Polsce, Warszawa 2007, s. 4-5, mps.

${ }^{28}$ Ojciec i nauczyciel. Kazania o św. Janie Bosko, red. W. Kołyszko, Warszawa 1988. 
ści ${ }^{29}$.

\section{Publicystyka na temat św. Jana Bosko po zniesieniu cenzury}

Zmiana systemu rządów w Polsce po upadku komunizmu, a następnie 11 kwietnia 1990 r. zniesienie Głównego Urzędu Kontroli Prasy, Publikacji i Widowisk, zwanego popularnie cenzurą, znacząco ułatwiły i skróciły proces wydawania książek katolickich. Ponadto zniesienie wiz wjazdowych do krajów Europy zachodniej przyczyniły się do łatwiejszego i częstszego nawiązywania kontaktów ze znanymi salezjańskimi ośrodkami wydawniczymi i dokonywanie thumaczeń różnorodnych publikacji o św. Janie Bosko. W okresie wcześniejszym zdecydowanie dominowały życiorysy Wychowawcy Młodzieży o charakterze faktograficznym i pobożnościowo-dewocyjnym. Później zajmowano się ks. Bosko jako prekursorem szkolnictwa zawodowego, twórcy systemu prewencyjnego, a nawet nie pomijano milczeniem jego błędów i ludzkich niedoskonałości. Po zniesieniu cenzury w pełni odpowiadano na zapotrzebowania młodzieży i katolickiego społeczeństwa polskiego poprzez wznawianie poczytnych publikacji i wprowadzanie nowych na rynek wydawniczy, np. ks. R. Ukleja, Triumf Kościoła wedtug wizji św. Jana Bosko, Wrocław 1998.

Postacią ks. J. Bosko i jego publicystyką zajmowały się też środowiska poza salezjańskie, np. Wydawnictwo Diecezjalne w Sandomierzu i Księgarnia św. Wojciecha w Poznaniu ${ }^{30}$. W Wydawnictwie Sióstr Loretanek, staraniem Salezjańskiego Ośrodka Misyjnego w Warszawie wydano książę: Misyjny charyzmat księdza Bosko, red. S. Rafałko, Warszawa 2007.

Tabela 1. Wykaz książek poświęconych św. Janowi Bosko wydanych przez Wydawnictwo Salezjańskie w latach 1990-2010 ${ }^{31}$

\begin{tabular}{|c|l|c|}
\hline Rok & Autor (redaktor) - tytul & Nakl. egz. \\
\hline 1990 & A. Dietl, Święty Jan Bosko przyjaciel dzieci (wyd. 2.) & 50.000 \\
\hline 1990 & $\begin{array}{l}\text { F. Desramaut, Ksiądz Bosko i życie duchowe (Don Bosco e la vie } \\
\text { spirituale) }\end{array}$ & 5.000 \\
\hline 1990 & G. Getti, Niezwykte przygody świętego Jana Bosko & \\
\hline 1990 & W. Nigg, Święty naszych czasów & 20.000 \\
\hline 1990 & Sny, wizje świętego Jana Bosko & 30.000 \\
\hline 1990 & Święty Jan Bosko & 20.000 \\
\hline 1991 & T. Bosco, Ksiądz Bosko mówi do Ciebie & 5.000 \\
\hline 1991 & T. Bosco, Ksiądz Bosko wychowawca & 5.000 \\
\hline 1991 & F. Desramaut, Ksiądz Bosko i życie duchowe & \\
\hline
\end{tabular}

${ }^{29}$ Por. J. Jurczyński, Od tłumacza, w: Święty naszych czasów, s. 5.

${ }^{30}$ F. A. Forbs, Święty Jan Bosko. Przyjaciel młodzieży, Sandomierz 2007; P. Rupin, Dominik Savio. Nastoletni święty, Sandomierz 2008; E. Piotrowska, Święci uśmiechnięci. Święty Jan Bosko, Poznań 2010.

${ }^{31}$ Tabelę wykonano na podstawie Sprawozdań z działalności wydawniczej i katalogów wydawniczych 


\begin{tabular}{|c|c|c|}
\hline $\begin{array}{l}1991 \\
2001\end{array}$ & $\begin{array}{l}\text { L. Cian, Wychowanie w duchu ks. Bosko (Educhiamo i giovani } \\
\text { d'oggi come Don Bosco) }\end{array}$ & 5.000 \\
\hline $\begin{array}{l}1991, \\
2001\end{array}$ & H. Kączkowska, O Janku przyjacielu młodzieży & 40.000 \\
\hline 1991 & Sny, wizje świętego Jana Bosko & 30.000 \\
\hline 1994 & W. Goderski, Niesamowity ten ksiadz Bosko & 100.000 \\
\hline 1994 & L. Matt, H. Bosco, Ksiadz Bosko (Don Bosco) & \\
\hline 1996 & R. Weinschenk, Podstawy pedagogiki księdza Bosko & \\
\hline 1997 & E. J. Lutz, Uśmiechnięty aniol & \\
\hline $\begin{array}{l}1999, \\
2005\end{array}$ & $\begin{array}{l}\text { B. Ferrero, Rodzice szczéśliwi dzięki metodzie wychowawczej } \\
\text { księdza Bosko (Genitori felici con il sistema di Don Bosco) }\end{array}$ & \\
\hline 2000 & P. Dörfler, Ksiądz Bosko, przyjaciel młodzieży, król tobuzów & \\
\hline 2000 & J. Niewęgłowski (red), Ks. Bosko i jego system wychowawczy & \\
\hline $\begin{array}{l}2000, \\
2009\end{array}$ & K. Lothar, Ksiadz Bosko radosny do końca & \\
\hline 2000 & Ksiadz Bosko i jego system wychowawczy & \\
\hline 2000 & R. Weinschenk, Podstawy pedagogiki księdza Bosko & \\
\hline 2001 & $\begin{array}{l}\text { C. Bissoli, Jan Pawet II o systemie wychowawczym św. Jana } \\
\text { Bosko (Il Papa interpreta il sistema educativo di don Bosco) }\end{array}$ & \\
\hline $\begin{array}{l}2001, \\
2004 \\
2011\end{array}$ & P. Zerbino, (red), Sny Księdza Bosko (I sogni di Don Bosco) & \\
\hline 2001 & $\begin{array}{l}\text { U. Fontana, Relacja, sekretem wszelkiego powotania (Relazione, } \\
\text { segreto di ogni educazione) }\end{array}$ & \\
\hline 2002 & J. Biesmans, Człowiek serca Jan Bosko & \\
\hline 2002 & T. Bosco, Ztote myśli księdza Bosko (I pensieri di Don Bosco) & \\
\hline $\begin{array}{l}2002, \\
2005\end{array}$ & $\begin{array}{l}\text { A. Nożyńska Demianiuk (red.), Ksiądz Bosko mój przyjaciel } \\
\text { (Don Bosco mon ami) }\end{array}$ & \\
\hline $\begin{array}{l}2002, \\
2012\end{array}$ & $\begin{array}{l}\text { C. Russo, Ksiadz Bosko myśli na dobranoc (Don Bosco, pensieri } \\
\text { per una buonanotte) }\end{array}$ & \\
\hline 2004 & L. Mayer-Skumanz, Pozwólcie ptakom śpiewać & \\
\hline 2004 & T. Niewęgłowski (red.), Formacja Salezjanów Księdza Bosko & \\
\hline 2005 & Ksiądz Bosko przygoda jednego życia & \\
\hline 2006 & Misyjny świat Księdza Bosko - album, red. S. Rafałko & \\
\hline 2008 & R. Schiélč, 15 modlitewnych spotkań z księdzem Bosko & \\
\hline 2008 & T. Brezina, Michat Magone i prawdziwa odwaga & \\
\hline 2009 & $\begin{array}{l}\text { M. Michele, } 365 \text { kwiatków księdza Bosko (365 fioretti di Don } \\
\text { Bosco) }\end{array}$ & \\
\hline $\begin{array}{l}2009, \\
2011\end{array}$ & $\begin{array}{l}\text { T. Bosco, Ksiadz Bosko wspaniała historia (Don Bosco la } \\
\text { magnifica storia) }\end{array}$ & \\
\hline 2009 & $\begin{array}{l}\text { P. Cordula, P. Reinhold, Dzieci świętuja uroczystość Księdza } \\
\text { Bosko }\end{array}$ & \\
\hline 2009 & $\begin{array}{l}\text { S. Buksa, Doświadczenie wychowawcze św. Jana Bosko } \\
\text { w stużbie ewangelizacji }\end{array}$ & \\
\hline 2011 & $\begin{array}{l}\text { P. Farioli, Madonna Księdza Bosko (La Madonna di Don } \\
\text { Bosco) }\end{array}$ & \\
\hline
\end{tabular}




\section{„Mała Poligrafia” w Krakowie i jej rola w propagowaniu ks. Bosko}

Redakcja Nostry od początku do roku 2000 mieściła się w lokalach Inspektoratu Towarzystwa Salezjańskiego w Krakowie. Dla potrzeb wydawniczych systematycznie wyposażanoje w nowocześniejsze maszyny iurządzenia. Dopierow 1974 r. udało się sprowadzić zza granicy powielacz elektryczny. W latach 80 . w miarę możliwości instalowano maszyny drukarskie i w ten sposób powstała mała poligrafia, którą następnie przekształcono w drukarnię i Wydawnictwo Poligrafii ITS. Oprócz „Nostry” powielano tam, a później drukowano materiały hagiograficzne, duszpastersko-katechetyczne i powołaniowe ${ }^{32}$.

Właśnie tu staraniem i pod redakcją ks. Józefa Króla na powielaczu, w formacie A4 wyszło thumaczenie ks. A. Chiavarino, Radosny święty. Zbiór faktów i wydarzeń ż życia świętego Jana Bosko, Kraków 1975, ss. 197. Ta sama pozycja w nieco zmienionej formie została wydana w roku 1987 nakładzie 2000 egzemplarzy na małej poligrafii do użytku wewnętrznego. Był to zbiór drobnych opowiadań, wydarzeń zanotowanych przez ludzi współczesnych Świętemu. Pozycję wznowiono w związku z uczczeniem setnej rocznicy śmierci ks. Bosko oraz celem upowszechnienia idei którą on głosił - „służcie Panu w radości”33.

W ramach tych jubileuszowych obchodów (27 i 28 listopada 1987 r.), ks. prof. Mieczysław Majewski SDB, wraz z Sekcją Katechetyczną KUL, zorganizował sympozjum naukowe na temat: „Wychowanie chrześcijańskie w duchu św. Jana Bosko". W ramach tego sympozjum salezjanie i salezjanki zaprezentowali pięć referatów i poprowadzili cztery konwersatoria. Rezultatem tego wydarzenia była pozycja książkowa pod tym samym tytułem ${ }^{34}$.

Srodowisko małej poligrafii zajmowało się także przekładem na język polski oficjalnych dokumentów Zgromadzenia. Tam też w 1991 r. ukazała się drukiem „Duchowość salezjańska”, autorstwa przełożonego generalnego ks. E. Vigano. W 1994 r. thumaczeniu ks. Tadeusza Jani SDB w Poligrafii Inspektoratu Towarzystwa Salezjańskiego w Krakowie wyszły drukiem trzy książki Józefa Aubry: $S a$ lezjańska duchowość apostolska; W szkole duchowej księdza Bosko; Testament duchowy.

Ks. J. Jurczyński przetłumaczył z języka niemieckiego pozycję Wolfganga Goderskiego, Unglaublich dieser Don Bosco (Święty Jan Bosko. Przyjaciel dzieci ulicy), Kraków 2001, ss. 187, oraz książkę Giorgio Fanciulli, Don Bosco (Święty Jan Bosko przyjaciel młodzieży, Kraków 2001, ss. 135. Normalnym już drukiem, formatu B5 w Wydawnictwie Poligrafii ITS w Krakowie w przekładzie i opracowaniu ks. Tadeusza Jani ukazała się cenna pozycja ks. Moranda Wirtha SDB,

${ }^{32}$ AAN Wd/sW, sygn. 133/126, A. Merker do F. Adamiaka Wiceprezesa Głównego Urzędu Kontroli Prasy, Publikacji i Widowisk, Warszawa 5 VIII 1975; Pro memoria. Inwestycje. Ks. A. Dziędziel, Kraków 20 IV 1976; K. Szczerba, Sprawozdanie ze stanu Inspektorii św. Jacka za okres kadencji na stanowisku Przełożonego Prowincji ks. Mgra Mieczysława Kaczmarzyka od zaprzysiężenia 25 IX 1976 do 17 VIII 1982 r., „Nostra. Biuletyn Salezjański”, 1982, nr. 222-223, s. 35.

${ }^{33}$ Por. M. Dziubiński, Wprowadzenie, w: Ks. G. A. Chiavarino, Radosny święty, s. 3-4.

${ }^{34}$ ASIW, t. Sympozja, Program sympozjum; S. Jędrzejewski, Sympozjum, Wychowanie chrześcijańskie w duchu św. Jana Bosko. Katolicki Uniwersytet Lubelski 26-27 XI 1987, Biuletyn Salezjański. Nostra”, 1988 nr 287, s. 35-36; Wychowanie chrześcijańskie w duchu św. Jana Bosko, red. M. Majewski, Kraków 1988, ss. 150 (mała poligrafia). 
Ksiadz Bosko i Rodzina Salezjańska. Dzieje i nowe wyzwania (1815-2000) (Da Don Bosco ai nostri giorni. Tra storia e nuove sfide 1815-2000), Kraków 2009, ss. 552. Autor przedstawił dzieje Towarzystwa Salezjańskiego na tle ogólnej panoramy Kościoła i świata. Tekst ubogacił tablicami chronologicznymi ważniejszych wydarzeń, danymi statystycznymi i obszerną bibliografią, w której uwzględnił najważniejsze polskie publikacje ${ }^{35}$.

W Poligrafii Salezjańskiej wydano obszerną pracę ks. Józefa Marszałka pt. Personalizm i pedagogia prewencyjna ks. Jana Bosko, Kraków 2010. Autor podjął próbę ukazania elementów personalizmu współczesnego w systemie prewencyjnym. Ks. Marszałek zaprezentował też szeroki stan badań z zakresu współczesnej pedagogiki salezjańskiej.

\section{Wkład salezjanów pracujących wśród Polonii zagranicznej}

Na polu wydawniczym w propagowaniu osoby i czynów ks. Jana Bosko wydatnie zaznaczyły swoją obecność polskie środowiska emigracyjne. Nakładem salezjanów pracujących w ośrodku polskim w Ramsey koło Nowego Yorku w Międzynarodowej Spółce Wydawniczej w Turynie w 1921 r. wydrukowano (na 552 stronach) obszerną pracę ks. Jana Bonettiego, Poczatki dzieła ks. Bosko czyli 25-lecie Oratorium (Cinque lustri di storia dell' Oratorio Salesiano fon dato dal sacerdote D. Giovanni Bosco, Torino 1892). Analogiczną drogę wydawniczą miała pozycja J. Kassana, Ks. Bosko opowiadanie dla młodzieży, Ramsey NY, ss. 195 w thumaczeniu ks. Władysława Klimczyka (La Giovinezza di d. Bosco, Torino 1920). Ks. Marcin Massalski z języka niemieckiego przełożył popularne opowiadanie autorstwa Pawła Walle pt. Wiel. Ks. Jan Bosko, Ramsey 1922. Koszty druku sfinansowali polscy salezjanie pracujący w Ramsey N. Y. - ośrodku dydaktycznowychowawczym dla Polaków w Stanach Zjednoczonych. W 1950 r., za rządów komunistycznych w Polsce, w języku polskim i w pięknej szacie graficznej, wydano w Ramsey Ustawy i Regulaminy Towarzystwa św. Franciszka Salezego, które następnie sprowadzono do $\mathrm{kraju}^{36}$.

Były kapelan wojskowy, ks. Józef Czerniecki (1909-1996), pracujący wśród Polaków w Wielkiej Brytanii, sfinalizował koszty druku i przesyłki książki Wilhelma Hünermanna Apostoł Młodych święty Jan Bosko, nakładem Katolickiego Ośrodka Wydawniczego „Veritas”. London 1977 ss. 254. Biografia ukazała się w serii niebieskiej „Biblioteki Polskiej”. Główny inspirator tego przedsięwzięcia dr Stefan Sołtyszewski wykonał też przekład polski z języka francuskiego ${ }^{37}$.

Dzięki zaangażowaniu salezjanów polskich pracujących na Papieskim Uniwersytecie Salezjańskim w Rzymie w 1980 r. przetłumaczono z języka włoskiego na polski Spetniony sen. Opowieść biograficzna o świętym Janie Bosko (Don Bo-

${ }^{35}$ Por. Wirth, Ksiadz Bosko i Rodzina Salezjańska, s. 25, 443-509.

${ }^{36}$ Por. S. Pływaczyk, Zarys działalności salezjanów polskich w USA, Ramsey 1974, mps.

${ }^{37}$ Inspektor krakowski w Pro Memoria do Ud/sW w Warszawie wśród inwestycji na rok 1977 podał „Wydanie drukiem żywot św. Jan Bosko w Anglii i zezwolenie na sprowadzenie do raju”, AAN Ud/sW, syng. 133/126, ks. A. Dziędziel do Ud/sW, Kraków 20 IV 1976. 
sco - una biografia nuova) popularnego pisarza Teresio Bosco. Książkę wydrukowano u księży Marianów w Rzymie, a koszty z tym związane pokryła dobrodziejka salezjanów, Elena Spirelli z Mediolanu ${ }^{38}$.

\section{Pisma księdza Jana Bosko wydane w języku polskim}

Salezjanie polscy pierwszego pokolenia znali dość dobrze język włoski. Mimo to przetłumaczyli na język ojczysty kilka najbardziej popularnych i wznawianych książek napisanych przez ks. Bosko. Z pewnością zależało im na dostarczeniu lektury dla odbiorców posłannictwa, tj. chłopców w ośrodkach dydaktycznowychowawczych jak i zapoznanie szerszego grona społeczeństwa z kolebką Zgromadzenia na Valdocco w Turynie.

Jedną z pierwszych pozycji autorstwa ks. Jana Bosko wydanych po polsku był Młodzieniec zaopatrzony w praktyki pobożności chrześcijańskiej, który ukazał się w 1905 r. nakładem Zakładu Salezjańskiego w Oświęcimiu, ss. 721 . Od 1847 r. do śmierci autora (1888) ukazało się ponad 100 wydań tego „podręcznika” w języku włoskim. Na początku modlitewnik ten zawiera 22 rozważania duchowe. W drugiej części znajdują się propozycje praktyk pobożności chrześcijańskiej. Część trzecia dotyczy kultu: Matki Bożej, świętych, zmarłych. W kolejnym paragrafie podano zasady wiary chrześcijańskiej oraz psalmy, kantyki, hymny, sekwencje. Ponadto w układzie tematycznym zebrano także pieśni kościelne ${ }^{39}$.

W środowisku oświęcimskim opublikowano również Życiorys Stugi Bożego Dominika Savio napisany przez ks. Bosko, Oświęcim 1913, ss. 179. Biogram ten został wznowiony w 1918 r. w Krakowie, ss. 184. W roku 2002 pod zmienionym tytułem, Życie świętego Dominika Savio. Wychowanka z Oratorium św. Franciszka Salezego, ukazał się w Wydawnictwie Salezjańskim. Ostatnio w 2009 r. w tymże wydawnictwie ukazała się kolejna edycja pt. Życie świętego Dominika Savio (Vita di San Domenico Savio). Wychowawca Młodzieży na przykładzie historii życia wychowanka pierwszego Oratorium salezjańskiego dał swoim podopiecznym konkretny wzór dobrego postępowania ${ }^{40}$. Kolejną pozycją autorstwa św. Jana Bosko wydaną w języku polskim są Rozważania Majowe ks. Jana Bosko (Il mese di maggio consacrato Maria ss. Immacolata), które przetłumaczył ks. ksiądz Bogdan Walczykiewicz, a wydało w 2003 r. Wydawnictwo Towarzystwa Chrystusowego Hlondianum w Poznaniu (ss. 159).

Czytelnikowi polskiemu umożliwiono zapoznanie się jeszcze z dwoma drukowanymi biogramami chłopców, którzy zmarli w młodym wieku, a których krótkie życie upamiętnił osobnymi publikacjami Ks. Bosko. W roku 1926 w Wydawnictwie Salezjańskim w Warszawie wydano: Życiorys młodzieniaszka Michała Magone, wyd. 1, 2, ss. 130 i Pastuszek alpejski czyli życiorys młodzieniaszka

${ }^{38}$ Por. J. Pietrzykowski, Salezjanie w Polsce 1945-1989, Warszawa 2007, s. 364.

${ }^{39}$ Por. J. Bosko, Młodzieniec zaopatrzony, Oświęcim 1905, s. 709-721. Trzecie wydanie rozszerzone i poprawione pt. Przewodnik Młodzieży na drodze pobożności chrześcijańskiej ukazało się w roku 1931 w Wydawnictwie Salezjańskim w Warszawie, ss. 454.

${ }^{40}$ Por. Jan Bosko, Życiorys Stugi Bożego Dominika Savio, Kraków 1918, s. 2-3. 
Franciszka Besucco, ss. $154^{41}$.

$\mathrm{Z}$ powodu represyjnej cenzury wydawanie kolejnych książek autorstwa ks. Bosko okazały się niemożliwe. W 1956 r. w Łodzi do użytku wewnętrznego, na powielaczu anonimowo opublikowano w trzech częściach, Św. Jan Bosko do swoich synów, cz. 1. ss. 117, cz. 2, ss. 76; cz. 3, ss. 144. Każde z zamieszczonych opowiadań zostało odpowiednio udokumentowane przy spisach treści ${ }^{42}$.

Zainteresowanie życiorysami napisanymi przez ks. J. Bosko wykazało się w sposób szczególny Wydawnictwo Diecezji Sandomierskiej. Ostatnio ukazały się w nim aż trzy krótkie biografie poświęcone koledze z lat seminaryjnych: Ludwik Comollo. Wzór młodych (Le vie de Louis Comollo), Sandomierz 2010 i dwóch wychowanków oratorium: Michat Magone. Dziecko ulicy (Le vie de Michel Magon), Sandomierz 2008, Franciszek Besucco, Sandomierz 2011 ${ }^{43}$.

Na polecenie papieża bł. Piusa IX w 1863 r. ks. Bosko zaczął opisywać dzieje swojego życia, którymi zapełnił trzy grube zeszyty rękopisu. Pierwsze próby ich wydania w 1946 r. podjął historyk Towarzystwa Salezjańskiego, ks. E. Ceria. Po kilkudziesięciu latach tekst ten uwspółcześnił T. Bosco, z którego dokonano przekładu na język polski. Książka: Św. Jan Bosko, Wspomnienia Oratorium, Warszawa 1987, ss. 240 ukazała się w Wydawnictwie Salezjańskim w nakładzie 5.000 egzemplarzy. Pozycja ta została opatrzona aparatem naukowym i wykazem ważniejszych dat w życiu ks. Bosko. Jest ona traktowana jako pewnego rodzaju źródło do genezy i początków Zgromadzenia ${ }^{44}$.

$\mathrm{Z}$ niniejszego opracowania wynika, że postać św. Jana Bosko od początku cieszyła się dużą popularnością i zainteresowaniem wśród Polaków. Przed przybyciem salezjanów na ziemie polskie - w ograniczonym zakresie - wydawano już życiorysy świętego i rozprowadzano jego czasopismo. Salezjanie przez cały burzliwy XX wiek na miarę swoich możliwości propagowali zarówno osobę Apostoła Turynu oraz jego dzieła apostolskie i misyjne. Zbliżająca się w roku 2015 dwusetna rocznica urodzin św. Jana Bosko jest okazją do zaprezentowania historiografii polskiej poświęconej wielkiego wychowawcy młodzieży męskiej.

\footnotetext{
${ }^{41}$ Por. Bosko, Michat Magone, s. 122-123; Pastuszek alpejski, s. 6-7.

${ }^{42}$ Św. Jan Bosko do swoich synów, cz. 1-3, Łódź 1956.

${ }^{43}$ http://www.wds.pl/index.php?=88\&=1 z 24 IX 2012.

${ }^{44}$ Por. Bosko, Wspomnienia Oratorium, s. 56, 227-232.
} 


\section{POLISH PUBLICATIONS ABOUT ST. JOHN BOSCO}

\section{Summary}

The author of this article showed the positive role of the religious book and press informing the Polish society of the life and activity of the founder of the Society of Saint Francis de Sales. Even in the lifespan of St. John Bosco, his biographies were translated into Polish and printed in Cracow, Lvov, Poznan and Warsaw. Since 1898, the Polish edition of the Salesian Bulletin entitled „Wiadomości Salezjańskie”, which soon became „Pokłosie Salezjańskie” (in 1916). Between the two world wars, the most publications about St. John Bosco came out owing to his beatification and canonization $(1929,1934)$. After the War II „Pokłosie Salezjańskie” was being edited until the close-down of the publishing office (1949). The Salesians revived Salesian Publications during the time of the communist censorship (1976), they managed to publish several biographies of St. John Bosco, and two books dedicated to him bring from abroad ( Italy, the UK). Articles on the subject of the Great Educator of the young were published in the internal periodical - „Nostra”, and in the annual „Seminare” which was not coming out on a regular basis in 1975-1988. After having initiated cooperation with the publication Elle Di Ci in Turin, the Polish reader has access to a wide spectrum of books edited in the Salesian Society worldwide. 